\title{
CRISIS, TENSIONS, INSECURITY AND MORE FRACTURES: WHAT HAPPENED TO THE SOUTH AMERICAN DEFENCE COUNCIL?
}

\begin{abstract}
ROGELIO PLÁCIDO SÁNCHEZ LEVIS
rogelio.sanchez@iaen.edu.ec

Lecturer and researcher at the Institute of Higher National Studies (Instituto de Altos Estudios Nacionales, IAEN, Ecuador). Lecturer, international analyst, former diplomat and career ambassador, and expert in Negotiation and Conflict Theory
\end{abstract}

DIEGO PÉREZ ENRÍQUEZ

diego.perez@iaen.edu.ec

Doctor in Political Science from the University of Belgrano. Holder of a Master Degree in International Relations from Universidad Andina Simón Bolívar, Quito, holder of a scholarship for the preparation of master thesis: "The construction of the white paper on the defence of Ecuador" (La construcción del libro blanco de la defensa del Ecuador). Holder of a first Degree in Political Science and Law from Universidad Internacional del Ecuador. Academic Director of the Legislative School of the National Assembly (Ecuador). Previously, he served as coordinator of the IAEN Security, Peace and Defence area, where he was also dean of the School of Strategic Studies and Security, and of the School of International Policy and Security.

\section{Abstract}

The stalemate and crisis UNASUR finds itself have generated a great diversity of interpretations about their causes and consequences. In this context, the situation of the South American Defence Council (CDS) deserves particular attention, due to its relevance in the construction of greater autonomy for South America vis-a-vis global hegemonic processes and players. This article aims to open some lines of reflection on the causes of the weak impact and stagnation of the aforementioned Council.

\section{Keywords}

Crisis, Regionalism, Security, South America, Institutional

\section{How to cite this article}

Levis, Rogelio Plácido Sánchez; Enríquez, Diego Pérez (2020). "Crisis, tensions, insecurity and more fractures: What happened to the South American Defence Council?". In Janus.net, ejournal of international relations. Vol. 11, No. 2 Consulted [online] at date of last visit, DOI: https://doi.org/10.26619/1647-7251.11.2.3

Article received on July 23, 2019 and accepted for publication on March 20, 2020

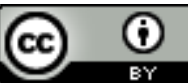




\title{
CRISIS, TENSIONS, INSECURITY AND MORE FRACTURES: WHAT HAPPENED TO THE SOUTH AMERICAN DEFENCE COUNCIL? ${ }^{1}$
}

\author{
ROGELIO PLÁCIDO SÁNCHEZ LEVIS
}

\author{
DIEGO PÉREZ ENRÍQUEZ
}

\section{Introduction}

This article was based on the discussions carried out in the framework of the research project on the South American identity of security and defence that took place between 2017 and 2018 at the Institute of Higher National Studies (IAEN) of Ecuador.

The creation of the South American Defence Council (CDS) and its intention to "Build a South American identity in defence matters that takes into account sub-regional and national characteristics and contributes to the strengthening of the unity of Latin America and the Caribbean" (UNASUR, 2009), raised expectations in political, governmental, social and academic circles that received with enthusiasm and hope the initiative that recovered the hopes and efforts made at important moments of the political history of South America. It was felt that this would lead to autonomous discussion, analysis and decision about issues associated with the aforementioned areas.

The intention to strengthen regional ties in defence matters is nothing new. From the Saavedra Lamas Non-Aggression Treaty of 1933 to the Inter-American Treaty of Reciprocal Assistance (TIAR) of 1947, there have been several proposals in this regard. Some sought to exclude the United States, as was the original purpose of Saavedra Lamas, while others sought to include it, as was the case with TIAR (Comini, 2010).

The crisis the Union of South American Nations (UNASUR) has plunged into led to this article. The various interpretations of, and approaches to this situation, has led us to propose a reflection on the space that welcomed the discussions and common decisions in the fields of security and defence. Even though circumstances, priorities and actors have changed, it is a matter of particular relevance, since it keeps the integration problem in the field of defence at the centre of the discussion.

1 Article translated by Carolina Peralta. 
This analysis aims to open a discussion about the CDS at a time when UNASUR faces regression, delegitimization and weakening, for not acknowledging that its demise constitutes one of the few options in the current scenario.

From its inception, UNASUR aroused enthusiasm and expectations in leaders, governments and diverse sectors in the region. For Venezuelan President Hugo Chávez, the organization constituted "a political body, a great leap forward" (Chávez, 2010). On his side, Cardoso from Brazil, perceived it as the prelude to the "United States of South America" (Cardoso 2000, cited in Gudynas, 2006). His successor, Luis Ignacio da Silva, insisted that a united South America would move "the board of power in the world" (Lula, 2008, cited in Visca, 2008).

UNASUR arose in a context dominated by the processes of restructuring global power accompanied by rises, declines, conflict and agreement between the main world powers - progressive political alternations in key countries in the region; the force used by Brazil at a time when its historical project of becoming a major power was being renewed; the relative decline in US influence over regional affairs; the significant increase in prices and, consequently, in income from raw materials ("commodities boom") that tended to widen the margins for policies (internal and external) that were much more autonomous regarding the global hegemonic centres; and a discourse that emphasized the need to overcome the dispersion and ineffectiveness of the strategic models of regional integration, and to have long-term state policies able to build solid institutional capacities free from cleavages, crises and political ups and downs.

The withdrawal by the majority of the progressive political forces in the region - generally more prone to autonomization, coordination, concertation and diversification of their foreign policies - the physical disappearance of their main inspirers, and the absence of convincing results in favour of integration, plunged UNASUR into a severe crisis, which, according to the speeches and the facts, seems to place it on the path of disappearance. However, it would be hasty to suggest that its opportuneness has disappeared, if one considers objectives that, for the moment, still seem to remain, at least in discursive terms: sovereignty and defence of natural resources, promotion of the integration of physical and energy infrastructures, encouragement of intra-regional trade, diversification of extra-regional links, and the coordination of foreign policies on issues of common interest, among others.

The same applies to issues associated with security that have also been UNASUR areas of intervention, which are not addressed in this article: the fight against organized crime, terrorism and transnational threats, among others. UNASUR had institutional bodies to address these matters, such as the South American Council on the World Drug Problem (CSPMD), and the South American Council on Citizen Security, Justice and Coordination of Actions against Transnational Organized Crime.

The security problems associated with the massive and uncontrolled flow of Venezuelan migrants, the tensions and criminality on the northern Ecuadorian border, the suspicions generated by the Colombian status of "global partner" of NATO (NATO, 2018), the threats of military intervention in Venezuela, and the continued production and trafficking of illicit substances (UNODC, 2018) exposed the unused UNASUR's capacities. This article aims to propose some lines of discussion on the factors that limited the institutional maturation of the CDS, in the event that its revival and readjustment are decided. 
The academic production on this topic has been diverse in terms of approaches. They have included disputes for control of the hemispheric agenda and hegemony over strategic security representations (Padula, 2015; Sánchez-Levis, 2019; Teixeira, 2010; Sanahuja \& Verdes-Montenegro, 2010); the influence of political, ideological and geopolitical factors on the maturation of the CDS (Paladines, 2017); and the particularities of its institutional construction (Ugarte, 2009).

What explains the limitations of the CDS in fulfilling its objectives? This is the main guiding question of our research. Likewise, two more questions are proposed: what role do the features that determine the particularity of the regional security complex (RSC) in which the CDS was founded play? To what extent could the shortcomings of its institutional construction compromise the achievement of its declared objectives?

The following hypothesis is advanced: the stagnation and poor results of the CDS are due to some features that characterize the South American RSC (US advance, fears of future overlap of Brazilian interests, and fractures in the social construction of threats), and the weaknesses of its institutional construction.

This article is the result of an empirical study focused on the description of the intertwined processes that shaped the development of the CDS, guided its discourse and were present in the emergence and resolution of the crises faced by the aforementioned organization. The methodological strategy was designed considering, first, the breadth and richness of the contributions from direct oral sources (officials from UNASUR, the Centre for Strategic Defence Studies (CEED), governments of the region, etc.); second, the access to official documents of the aforementioned institutions; and third, the possibility of starting discussions with experts, researchers and officials. On the other hand, the interviews, debates and consultations with secondary sources contributed to substantiate and broaden the initial perspective of the work.

The combined look at the object of this research, from the neo-institutionalist theoretical perspective and of the Regional Security Complexes (RSC), are justified by the need to examine a phenomenon that has been insufficiently studied from these approaches, and the possibility of producing an original analysis that examines the reasons why such timid advances were made in the development of a regional security and defence forum, despite the confluence of political, historical-structural and institutional factors that may have acted in favour of its consolidation.

The theoretical contributions of the Copenhagen School ${ }^{2}$ were essential for this work. Two of its exponents, Barry Buzan and Ole Waever, define the RSC as a substructure of the international system with relative interdependence between its units in the field of security, and indifference towards the environment units. A first line of debate is opened here before the evidence that indicates the relevance of the United States in the security calculations of South American countries, and in the design and application of their public policies. This relocates the discussions on the "penetration" of the RSC phenomenon, which is part of the aforementioned theoretical model.

2 Academic forum that was born out of the discussions about the book "People, State and Fear: The Problem of National Security in International Relations, published in 1983. Its analyses focused on non-military security issues, which was a turning point with respect to traditional approaches. 
The aforementioned authors include four variables in the essential structure of the RSC: differentiation from its neighbours, anarchic structure, polarity, and social construction. According to the theorists, South America constitutes a "sub-conflictual anomaly" given the secondary nature of interstate security dynamics with respect to domestic affairs, the low use of military force, limited wars, high degree of political violence, intense relationship with the neighbouring superpower, and the possibility of splitting the RSC into two subcomplexes, among other features. From the previous characterization, some elements emerge that exert a considerable influence on the evolution of the Complex, and in particular on the creation of favourable conditions for its institutionalization, which correspond to the following lines of debate.

First, the differentiation of the South American RSC with respect to its neighbours. Even though Buzan \& Waever (2003) define South America as a RSC, based on the thesis of indifference with respect to the dynamics of other RSCs, the evidences that indicate the "penetration" and the relevance of the United States in the calculations of security of the South American countries, lead to the discussion of the extent to which this could limit the institutionalization of the Complex towards an autonomous framework to address and solve its conflicts and external dangers. According to the aforementioned theory, security problems are resolved within the region with alliances circumscribed to its physical space, while the action of external global actors, although influencing the capacities of the units, does not shape its inner structure. However, in the case of Washington, it is not an external power that simply aligns itself with a state or group of states, but a central actor of the international system that perceives the region as a zone of influence where it massively deploys resources and capacities. In addition, there is its geographical proximity, the dimensions of its material power and means, and its networks and influence mechanisms (OAS and the Inter-American System). The other element to consider is the US response to the development of the Brazilian "global player" project that could contribute to deepening penetration, and therefore accentuate the anomalous profile of the South American RSC.

In these specific conditions, obstacles are identified in the face of efforts to empower the discourses and common spatial practices of foreign policy and external security. Consequently, a RSC that is subject to high penetration will find serious limits to its development, running the risk of stagnation, to the extent that it needs relevant actors from other complexes to solve part of its security concerns.

Second, polarity constitutes one of the features that distinguishes the South American RSC. There is no hyper concentration of resources and capacities to stimulate the "overlap" dynamics and the will to impose stemming from asymmetric relationships, on the one hand, and accept hegemonic approaches in terms of conceptions, representations and spatial policies, on the other.

However, it is obvious that the Brazilian global power project generates suspicions, reservations and fears on the part of many regional capitals and staff, considering the need to accumulate material and ideological power that this process entails, and its consequences on distribution and regional power structure. In fact, the launch of the CDS initiative demanded from Brasilia huge diplomatic efforts regarding its acceptance and subsequent materialization. In these circumstances, a RSC will find quite a few difficulties to express itself in institutional terms. 
Third, the social construction of threats and dangers, as well as the diverse ways in which discourses, spatial policies and material networks destined to confront them are represented, submerge and find their causal links in the depths of the history of the region: decolonization, its founding as a political subject, the formation of its states and the construction of its very diverse strategic integration models. The main promoters of the CDS-UNASUR - especially Brazil and Venezuela - defended the idea of the relevance and opportunity of a space for autonomous discussions on security and defence as a way to increase the weight and relevance of the region on the world board; the nations closest to, and dependent on military cooperation with the United States tended to show resistance to the initiative and preserve ties with Washington, insisting that it was the only viable alternative to reduce their vulnerabilities and face external threats. It is this duality of myths that continues hamper the unification of visions and the consolidation of the project.

Therefore, the indisputable weight of the particularities of the political history of South America on the efforts to build a regional institutionality in matters of security, faced with the ancestral and persistent struggle between Monroism (Pan-Americanism) and Bolivarianism (autonomous regionalism) (Vasconcelos, 1937) is recognized; the same goes for the incessant rivalries between states; the interpretation of threats by its civil and military elites at national level (Nolte \& Wehner, 2015); and the influence of the armies in the formation of deeply rooted national imaginaries that are associated with sovereignty and territorial control (Manero, 2007), with a marked tendency to import foreign models of interpretation, analysis, and treatment of external challenges and dangers.

The assumption of South America as a Regional Security Complex (RSC), considering the strong interdependence between its units, for the resolution of its security problems, is combined with identifying the CDS as one of its institutional expressions. The findings obtained by the research informing this article allow us to see that the development and the particular configuration of a RSC shape and influence the behaviour of existing institutions within it, regardless of the degree of interaction and interdependence of its members. Taking into account that the intersubjective processes not only result in the construction of threats, but also in the actions and decisions for their confrontation, reduction and/or elimination, it is considered that: 1 ) the persistent "penetration" of a RSC casts doubt on the "indifference" of one with respect to the other (one of its fundamental premises), facilitating the introduction of ideas, representations and material networks that can open competitive and fragmentary dynamics within the Complex; (2) the rise in terms of rank, power and influence of members of the Complex could introduce, in the future, very pronounced asymmetries and "overlap" with the capacity to compromise the anarchy and independence of their units, and consequently, their own existence; and (3) the social construction of threats to security fails to overcome the dispersion and diversity of its interpretation.

By way of generalization, within a CRS with anomalous features such as the South American one, the development of autonomous institutional forms can be difficult, given the consequences of the persistent "penetration" from a foreign Complex; the suspicions raised by the deepening of asymmetries in the face of actors with greater relative power and hegemonic claims, and the fear of seeing some "overlapping" features introduced in 
the future; and the diversity in social constructions about threats and dangers, which tend to inhibit the unification of their myth.

Even though the usefulness of the RSC Theory is recognized to address this paper's object of study, the truth is that it is not entirely sufficient to complete the analysis and have a more comprehensive internal look at its institutional expressions, as a differentiated phenomenon. For this reason, one of the many neo-institutionalist perspectives that address the institutionality issue, with emphasis on its normative framework (formal and informal), and its influence on the behaviour of groups and individuals was used. Within this broad field of knowledge, the sociological institutionalism of John Meyer and Brian Rowan (1977) was chosen, given their interest in the coupling (isomorphism) of organizations with their external institutional environments, as a guarantee for survival and success.

For us, within the institutional environment where international organizations operate, the constitutions and the political, state and legal systems that emanate from them dominate. This is defined as being dual, insofar as it combines the acceptance and promotion of external relations, with the defence of sovereign attributes, almost always with greater constitutional rank and political appreciation. In other words, it is possible, under specific circumstances, for organizations to submit to the consequences derived from a hostile external environment, reluctant to provide legitimacy and resources for their operation.

According to Meyer and Rowan (1977), organizations that "develop in highly elaborated institutional environments and manage to incorporate and reflect the forms of these environments, gain the legitimacy and the necessary resources to survive. This depends in part on environmental processes and the ability of leaders to deal with them" (352). Here it is worth outlining some considerations:

1) The development of structures and areas of discussion and decision external to the states, either through external cooperation formulas, explained through the liberal intergovernmentalism of David Moravcsik, or through more complete supranational schemes, argued from the functionalism of David Mitrany, or the neo-functionalism of Ernst Haas, will depend solely and exclusively on their will, which will continue to be, according to Cassese (1986), "the backbone of international society" (73), regardless of the proliferation of transnational actors and the restructuring of power to which the various post-Westphalian notions refer. The decision of the CDS members to conceive a forum limited to the exchange of ideas and information, without binding resolutions or a structure that would compromise absolute control over their policies and decisions, seems to be part of this logic.

2) Diez de Velazco (1997) defines international organizations as "voluntary associations of states established by international agreement, endowed with permanent bodies, their own and independent, in charge of managing collective interests and capable of expressing a will that is legally different from that of their members (41). However, the evidence found so far does not point to a desire, within the CDS, to develop its own independent legal personality, nor the scope of its political action beyond discussions about specific issues and cooperation projects . 
3) Unlike the institutions that are subject to domestic constitutional and legal norms, the international ones do not have another external institutional and legal framework of reference other than the state, which constitutes the source of legitimation and appropriation of resources for their survival. Consequently, its existence and development will depend on the perception and agreements between the forces and actors that collide and cooperate within the state fabric, on how they meet their expectations and satisfy particular and general interests.

The aforementioned factors suggest an insufficiently developed institutionality of the CDS, resulting from the weakness and laxity of its norms, the poor autonomy it has to achieve its objectives, and the persistent reluctance within the states about its viability and reason for existing.

In addition to the introduction, discussion of the results and conclusions, this article has four parts: the first is dedicated to the RSC and discussions about penetration; the second analyses the "overlap" and the misgivings raised by Brazil's leadership; the third is dedicated to the fractures of the social construction around threats to state security; and the fourth examines the CDS as an institutionalized form of the South American RSC.

\section{The Regional Security Complexes and the discussion about "penetration"}

The interest of the United States in the rich South American biodiversity, the bioceanic connections for the diversification and expansion of access to the Pacific Basin, Antarctica and the transpolar zones (of the South Atlantic, Indian and Pacific oceans), the "interpolar strip", the use of topography, water and energy resources, maritime and river corridors, and the control of social reproduction, among other regional assets, is evident. Classic geopolitics never stopped having the region under its radar. For Mackinder (1904), the development of the great potentialities of South America can have a decisive influence on the hegemonic system of the United States (Mackinder, 1904). Meanwhile, and according to Alfred Mahan, with the strategic dominance of the Panama Canal, the Atlantic coast would compete with Europe, on equal terms, in terms of distance, more than with the markets of East Asia (Mahan, 1912).

The support and impulse of the CDS-UNASUR was accompanied by careful diplomatic efforts from Brasilia to avoid, as far as possible, that it was perceived as an anti-US initiative. In fact, the most radical aspects of the Venezuelan proposal were moderated or eliminated (Cardoza, 2010; García, 2010; Montenegro, 201; Padula, 2015; Teixeira, 2010; Sánchez-Levis, 2019). On 22 March 2008, the Brazilian Defence Minister delivered the CDS proposal to the Inter-American Defence Board (IADB), a body dependent on the Organization of American States (OAS). He also met the Secretaries of Defence, Robert Gates, and of State, Condolezza Rice, to whom he clarified that in no case would it be a NATO-style military alliance. For Brasilia, it was about laying the foundations of a South American defence identity supported by three areas (Amazonian, River Plate, and 
Andean) and three common principles (sovereignty, territorial integrity and nonintervention) (CDS Working Group, 2009).

According to Buzan \& Waever (2003), it is "penetration" that links the general pattern of power distribution between global powers and the regional dynamics of the RSC. According to the authors, this occurs when external powers build security alliances with states within a Complex. According to the aforementioned scholars, a regional rivalry can provide opportunities or demands for great powers to penetrate the region, while the logic of the balance of power encourages local rivals to ask for external help, and, as a result, local patterns of regional rivalries are linked to global ones (p. 46). Even though the Regional Security Complex Theory (RSCT) declares that one of its purposes is to deconstruct the emphasis on the role of the great powers and enhance the weight of local factors in the security analysis of the region, in our view some aspects indicated by the aforementioned theorists about external penetration are arguable. These include the statement that "the pattern of conflict comes from factors internal to the region", and the approach that ensures that external powers cannot - even if they are heavily involved - define, de-securitize or reorganize the security agenda of the region (47).

The strategic importance of the Amazon basin in Brazil's discourse, representations, and geopolitical calculations has been extensively documented in the literature (Padula, 2015, 2013; Manero, 2007; Teixeira, 2010; Kersffeld, 2010). At the same time, it is assured that such geographical space will be created in the context of global rivalries and struggles (Rodríguez \& Plazas, 2012; Pastor, 2017; Navarro \& Bessi, 2017; Guevara, 2017). The interest expressed by the US military in its control and implementation; the declarations of the former Vice President and presidential candidate Albert Gore, stating that the Amazon, "contrary to the feelings of the Brazilians, belongs to all of us"; the similar words used by Brazil's former secretary of Justice, Romeu Tuma (Barrionuevo, 2018); the dimensions of the military architecture deployed in the region; and the conduction of military exercises like "AmazonLog 17" - with the active presence of American troops - constitutes empirical evidence of the discussion about the definitions of the RSCT regarding the autonomy of the South American RSC, and of the hypotheses that discards Washington's direct involvement in an armed conflict for the control of the zone in the future. ${ }^{3}$

The United States has about 800 military bases around the world, of which more than 76 are in Latin America. The best known are: 12 in Panama, 12 in Puerto Rico, 9 in Colombia and 8 in Peru. The majority are in Central America and the Caribbean. On the other hand, the North American Command, in March 2018, publicly informed about its strategy in the region for the next ten years, identifying the main "hazards" or "threats" and how to deal with them (Capote, 2018).

Admiral Kurt W. Tidd, commander of the South Command, addressed the Committee of the Armed Services of the Senate, after saying that corruption, violent crime, economic backwardness, Islamic fundamentalism, illegal and uncontrolled migration, instability,

3 The history of the military bases built by the United States government in Latin America is related to having to face potentially conflicting and strategic movements for its foreign policy, such as the construction of the Panama Canal, started in 1903, Cuba's independence in 1902, and Puerto Rico's in 1898. As a result of these facts, this form of protection of American interests was expressed in the creation of a network of bases in Latin America during the 20th century (Bitar, 2016). Nowadays, the maintenance of US military bases is justified by the war against drugs and terrorism (Bitar, 2016). 
trafficking in arms, drugs and human beings, money laundering, and the presence of global competitors such as Russia and China, formed part of the hemisphere's security environment; he stated that "an integrated approach was needed to approve the capacities of the authorities in joint, interinstitutional, international and nongovernmental communities." He declared that it was necessary to "mobilize, organize and unify its own strongholds and those of partners and allies, to expand the exchange of information and collaboration, and to align security activities and development of capabilities in such a way that short-term successes can be translated into long-term achievements, supported by an adaptive and inclusive regional security network (Tidd, 2018). ${ }^{4}$

On the one hand, the Joint Vision 2020 of the Joint Command of the United States Armed Forces says that "the joint strength must be able to achieve full control of the spectrum, with American forces operating unilaterally in combination with other countries, institutions and partners to defeat any opponent. At the same time, the document insisted on the need to "maintain forces abroad able to deploy immediately so that they control the full spectrum" (Joint-Chiefs-of-Staff, 2018).

The penetration is equally massive and forceful at institutional level. The OAS has an architecture surrounding security and defence. The meetings of the Ministers of Defence, Public Security, and Justice (Attorneys General) stand out as fora, as well as the specialized conferences of the States Parties to the Inter-American Convention against the Illicit Manufactoring of and Trafficking in Firearms, Munitions, Explosives, and Other Related Materials (CIFTA), the Sessions of the Inter-American Committee Against Terrorism (CICTE), and the Ordinary and Extraordinary Periods of Sessions of the InterAmerican Drug Abuse Control Commission (CICAD). There is also a Committee on Hemispheric Security. At the same time, conventions and treaties on hemispheric security, weapons, terrorism and disaster cases have been signed within this body (OAS, 2019).

The concept of hemispheric security stands out in the field of the penetration of the South American RSC. The Declaration on Security in the Americas, adopted by the OAS in October 2003, broadened the traditional definition of defending the security of states by incorporating new threats, concerns, and challenges, which include political, economic, social, health, and environmental aspects, considered from that moment as potential threats to security (Griffiths, 2007). In this sense, the risk of increased securitization of the region's problems, and of militarization as a response to confront them, cannot be ruled out, if one considers the historical trend of political intervention by the armed forces during authoritarian regimes or in the context of armed conflict or social instability, the US anti-drug and anti-terrorist strategies that promote a broader role for the armed forces in law enforcement, and the crises and inoperative systems of public safety of the region (Freeman, 2005; Martínez Á. , 2016; Fernández, 2012).

So far, the massive penetration by the United States in the RSC is evident, which is still far from the definition of "overlap", considering, according to the cited theoretical

4 These statements took place in a context marked by the use of Colombian bases by US troops, the reactivation of the 4th Fleet, the promulgation of the White Paper of the United States Air Mobility Command and the issuance of the document «Development and Strategic Planning» of the North American Southern Command (Comini, 2010). 
perspective, factors such as the autonomy of its units to define its security policies, friendship-enmity patterns, and the distribution of the bulk of resources and capacities among a group of regional powers that converge and disagree. However, the US influence on the fields of management and transformation of conflicts and threats through ideas, capacities and institutions, shows an anomaly with respect to the theoretical proposal in question, and calls into question the problem of "indifference", as shown in the data obtained.

The global struggles for access and control of the Amazon is another point of debate regarding the Regional Security Complex Theory, taking into account the possibility of unleashing, in the future, a military conflict with the direct participation of the United States, whose interest in the area has been manifest for several decades, attested by the persistent and extensive presence of troops, bases and exercises.

\section{Overlap: a scenario that can be discarded in the future?: Brazilian major power project in the face of asymmetric perceptions, rivalries and distrust}

Even though the region succeeded in establishing the UNASUR and its CDS, having overcome a past of wars and conflicts that compromised peace, stability and development as a whole, it can be said that asymmetries and misgivings persist, as well as a perception of these phenomena, which questions the idea of consolidating a project such as the CDS, which to some extent results from Brazil's will to conceive an autonomous cooperative security and defence model, under its leadership.

For this reason, beyond becoming a factor for promoting the institutionality of the CDS, according to the logic of the RSCT, the perceived asymmetry of material power of neighbouring countries vis-à-vis Brazil has become a relevant obstacle, temporarilly outmatched by affinities and favorable circumstances, but latent from the visions, interests, experiences and specific perceptions of sectors of the elites of these countries. 5 They appeared with certain logic, reluctance and reservations in the face of an initiative seen as supporting the Brazilian major power project.

The ambition of the Brazilian elites to raise their rank and weight at sub-regional, regional and international levels constitutes a process under construction that began several decades ago. The Getulio Vargas government was responsible for the modernization and centralization of the state, the promotion of the industry and the rapprochement with the

5 The struggles, rivalries, and misgivings between units that won or claimed some autonomy in the region, date back to long before independence. The distance and suspicion of Chile, Asunción and Montevideo regarding Buenos Aires was notorious; of Guayaquil regarding Lima and Colombia; of Charcas and Upper Peru regarding Lima; Quito's suspicion of the annexation to Greater Colombia project, etc. (Demélas, 2010, cited in Paladines, 2017, p. 39). After years of republican and independent life, the maturity of the political subject was not enough to appease the struggles and suspicions, which has a lot to do with the Hispanic heritage and the specific cultural, social and political conditions in which the South American states arose. A not inconsiderable influence was exerted by the geopolitical concepts and guidelines generated in Europe, and, especially those of German origin, permeated South America through the Liaison Officers of the Latin countries in Europe. In other words, the Armed Forces were the direct recipients of geopolitical knowledge, especially in the Higher Schools or War Academies of the armies. And derived from the stigmatization of geopolitics by the allies, this knowledge was circumscribed almost exclusively to the said bodies and estates, acquiring a national connotation through the application of geopolitical guidelines to the circumstances of each country (Toledo, 2017). 
United States, which was accompanied by its participation in World War II, and the recognition by Washington of its right to become a permanent member of the UN Security Council (Cardoza, 2010). This project has been continued by different types of governments - including the military - and political and economic situations that put it to the test.

Brazil's White Paper on Defence recognizes "a clear trend of cooperation in defence", reinforced by "the creation of the Union of South American Nations (UNASUR) and especially its Defence Council (CDS)", and the establishing of a "security community, motivated by the fact that neighbouring countries share common historical experiences, similar development challenges and democratic regimes, which facilitate mutual understanding and favour the peaceful accommodation of the various national interests" (Brazil-Government, White Paper on the Defence of Brazil, 2012: 33). Likewise, it reiterates the priority interest in the South Atlantic (38) and in the Amazon, highlighting the launch in 2010 of the New Strategic Agenda for Amazonian Cooperation (50).

With a prospective vision of the Brazilian global leadership project, the text "Brazil in 3 steps" identifies the preservation of the national territory with integration with South America as one of its needs and objectives (Presidency-Brazil, 2004: 18). It also cites considerations of the National Intelligence Council, adscript to the Central Intelligence Agency (CIA) of the United States, that Brazil will not achieve regional leadership in South America due to the scepticism of its neighbours and the mistrust generated by the emphasis on its own interests (117). The document emphasizes "the economic, political, social and cultural integration of the peoples of Latin America", in favour of the formation of a Latin American community of nations (p. 15).

The National Defence Strategy, for its part, insists on the importance of the integration of South America for the defence of Brazil, the promotion of regional military cooperation and the integration of defence industrial bases. It points to the CDS as a consultative mechanism that will prevent conflicts and promote cooperation and integration "without the participation of a country from outside the region" (17). It also gives priority to the Amazon region, stating that "it represents one of the centres of greatest interest for defence (14).

The aforementioned documents were integrated into an action platform of the Brazilian government that included the reactivation and modernization of its industrial production complex for defence, the approval of the Regulatory Decree of the National Mobilization Law (2008), the implementation of the Southern Border Exercises, and the requirement of the right to increase its nuclear energy production (Comini, 2010).

The creation of the CDS-UNASUR in 2008 was an initiative of Brazilian foreign policy. The then minister of the Brazilian government Nelson Jobim, following the guidance of President Lula da Silva, travelled to the countries of the region promoting the accession of South American countries. In this context, Brasilia kept insisting on possible interstate threats to sovereignty over the rich Brazilian and South American natural resources, especially in contexts of political crisis and international conflicts. The need for a deterrent force in the region was expounded, agreed in the framework of the CDS, and adequate to the defence of natural resources and the autonomous and leading role that Brazil and the region wish to achieve in the international system (Padula, 2015: 243). For Comini 
(2010), a flexible cooperation scheme between unequal members was sought, and determined by multiple and even contradictory tendencies.

The clear imprint of Brazil's national interests that promoted the CDS was evident. Let us now examine the views of relevant actors in the region such as Argentina, Colombia and Chile.

Argentina, for its part, from the beginning insisted on preserving MERCOSUR as the privileged forum to discuss and settle matters related to regional security. The Argentine law "Restructuring of the Armed Forces", stated that:

Art. 7. The levels of strategic management and planning will analyse, at international level, the probable development of a defence system within the framework of MERCOSUR, in order to consider the requirements for the restructuring of the armed forces that may be necessary as a result of those agreements (National Congress, 1998, p. 65).

According to Ugarte (2009), this reluctance is based on the fact that the subregional entity had already been the scene of intense and fruitful cooperation in the field of public security, organized in specialized ministerial meetings on aspects of subregional integration different from the economic ones, including security and defence, accompanied by the construction of proposals and projects, which were pushed away by the emergence of the CDS idea.

Beyond security, for García (2010), the position vis-à-vis UNASUR has been ambiguous in the Argentine case, since in the bureaucracies of that country there is still a feeling of mistrust regarding the Brazilian leadership in regional affairs, seeing UNASUR as part of Brazil's regional hegemony project, and harbouring the fear that by paying less attention to MERCOSUR - more important for Buenos Aires in strategic terms - Argentina will lose its international negotiation relative power (Giacalone, 2007 cited in García, 2010, p. 36).

However, the initial reluctance was dissipated with Brazil's support for the renewed Argentine claim around Las Malvinas (Falklands), the election of Néstor Kirchner as secretary of UNASUR (Cardoza, 2010), the economic rapprochement with Venezuela since 2005 in the energy, industrial and agricultural cooperation areas, regional public financing mechanisms such as the Bank of the South, and the Venezuelan purchase of a large part of the bonds of the onerous Argentine foreign debt (García, 2010).

The 1998 White Paper on the Defence of Argentina stated that understanding the current state of maturation of defence and security issues in the sub-region required examining the origin and evolution of this historic initiative (MERCOSUR) (...) (GovernmentArgentina, 1998: 27). In its 2010 edition, the existence and objectives of the CDSUNASUR are recognized, although it emphasizes the existence of "differentiated subregional dynamics", a Southern Cone, which in the areas of "defence and international security has the openness and transparency levels that resemble those of the early experience of European integration" (Government-Argentina, White Paper, 2010: 34, 37, 38). 
In the 2015 edition, a more resolute position in favour of the consolidation and qualitative progress of cooperation between the Latin America nations, in general, and South America in particular, appeared, with the creation of the CDS and the scientific complementation, technology and production of Defence projects. (GovernmentArgentina, White Paper on Defence 2015, 2015, p. 217). The deepening of the commitment to the regional organ could be associated with the sympathies of the Kirchner administrations for the regional autonomization processes, as well as ideological affinity with their main promoters. However, Ugarte (2009), Luongo (2018) and Livoti (2019) refer the reluctance and criticism of career officials of the Ministries of Foreign Affairs and Defence regarding the priority given to the CDS-UNASUR over that of MERCOSUR. The truth is that there is a widespread fear that the Brazilian commitment to UNASUR will end up making MERCOSUR flexible to the point of emptiness regarding its most ambitious objectives, particularly being a "customs union" (Gandásegui, Martins, \& Vommaro, 2015).

Despite all that has been said so far, we agree with Schenoni's (2014) approach regarding the factors that ended the Argentine-Brazilian rivalry: the behaviour of both actors, the nature of the political economy of each country, and their relative participation in regional power. Gandásegui, Martins, \& Vommaro (2015) emphasize that there is no longer a leadership struggle between the two powers. However, so far nothing indicates that all concerns, doubts and even fears have been cleared up regarding a country that stands out at regional level not only for its capacities but also for its complicated insertion and relationships history.

Colombia, as a secondary power, also sought to preserve its autonomy in the face of Brazil's rise. The equation could be even more complex when part of the answers are articulated within the alliance with the United States, which for Bogotá is essential. The initial reluctance of the country to join the CDS is known (Álvarez \& Ovando, 2009; Kersffeld, 2010; Flemes, Nolte, \& Wehner, 2011). In general, the attitude of the Colombian authorities can be explained by the fear of affecting the strategic alliance with Washington, the presence of players in solidarity with the armed groups with whom it maintains an internal conflict, as well as the fear of being trapped in a forum where it can be weakened in conflicts with countries such as Venezuela and Ecuador.

Faced with the hypothesis of the Brazilian hegemonic construction, Colombia maintained the relatively highest military budgets in the region, the lowest levels of economic interdependence with its emerging neighbour, and close commercial and strategic relations with the United States and other powers (Schenoni, 2014).

In Bogotá, the country's concern to protect economic sectors and build alternatives to Brazilian leadership in the region persists, including the signing of free trade agreements with the United States and the European Union, as well as the project of triangular integration outside the regional blocks that became the Pacific Alliance. The most conservative sectors of Colombian politics have always been suspicious of the Venezuelan-Brazilian entente and their interest in the domestic conflict, and sceptical about the real determination of the CDS to support Colombia in its confrontation with its huge internal challenges. Likewise, the misgivings about a structural reality of power that gives Brazil greater autonomy in its international positions continued (Pastrana, 2011). 
In the case of Chile, Brazil's promotion project does not seem to be indifferent to its civil and military elites. Even though the dominant Prussianism in the Chilean military sectors makes them assume a kind of "manifest destiny", with a nation surrounded by real and potential enemies (Maldonado, 1998 cited in Montenegro, 2011: 117); and its condition as regional secondary power forces it to take certain precautions to preserve an acceptable margin of autonomy; the truth is that Chile's official narrative does not tend to express great concern about the rise of Brazil, nor its willingness to lead the process of building a regional discussion forum on issues related to security.

Santiago's accession to UNASUR had a fairly broad consensus within Chilean society, influenced by perceptions regarding the transnational nature of some problems and, therefore, the existence of common interests due to greater interdependence. The fact that the regional organization is not perceived as a danger also matters, since it does not interfere with the country's economic opening strategy. Let us remember that within UNASUR, it was decided to put aside the implementation of trade agreements and the transfer of sovereignty, due to lack of consensus among the members on these issues (Serrano, 2017).

For Chile, UNASUR has been a framework to mitigate the potential for instability and conflict with Bolivia and Argentina, improve its energy security and access to South American gas, avoiding the difficult relationship with La Paz, and facilitate the access of its exports to the regional market, without submitting to the requirements of MERCOSUR (Borda, 2012). "In the acceleration of geopolitics in the region, there are alliances that could be altered from their immediacy and appear distant from their long history. But in the case of Chile and Brazil, the accommodations and adjustments will not affect the organic and fundamental unity between these two nations" (Rivas, 2019).

In our view, the Chilean National Defence Book (2017) provides evidence of the state's will to diversify its interconnections, fora and spaces for the discussion of problems associated with security. Clearly, the CDS is not "the option" for Santiago, but one of many, with the government refraining from wasting the possibilities offered by each alternative to strengthen its defensive capabilities against traditional and non-traditional threats. According to this logic, it could be stated that although Chilean spatial practices and discourse try to produce adequate margins of autonomy and manoeuvre in the face of regional hegemonic dynamics, in the specific case of Brazil, the dense relationship, collaboration and understanding between the two countries is actively used to complement capacities and reduce its vulnerabilities. The aforementioned document states:

From an institutional perspective, the continent has gradually gained a complex and multilevel architecture of cooperation regimes in the various geographic areas in matters of security and defence. At continental level, Chile participates in the security and defence institutions of the InterAmerican System. (...). In the specific sphere of the continental level of defence, the Conference of Defence Ministers of the Americas has gradually developed as the most important political forum in the area of defence of the inter-American system, cooperative in nature, (...)"(Government-Chile, 2017, p. 87). 
"A second level of security practice in the continent corresponds to that of the Latin American and Caribbean region, which has gradually gained institutions and whose general situation contrasts positively with the global context of growing uncertainty and instability that is occurring and summarized in the previous sections (...). The practice of Latin American regionalism has also taken important steps in recent years, with the creation of the Community of Latin American and Caribbean States (CELAC), the Union of South American Nations (UNASUR) and its South American Defence Council (CDS) and, more recently, of the Pacific Alliance" (...)"(Government-Chile, 2017, p. 88).

From the perspective of the RSCT, we went beyond the level of the unit (State/ Government), encompassing other security aspects within it, such as the "influential groups", defined therein. For the purposes of this study, we worked with bureaucracies and high-ranking military commanders, taking into account their contribution to the constructions of imaginaries in terms of external threats and dangers.

The data collected shows differentiated attitudes and degrees of loyalty towards the CDS on the part of the elites of the selected countries, with direct consequences on their institutional maturation processes. The tensions in the discursive structure ${ }^{6}$ of the mentioned organ, gradually dissipated at political level, as the ideological affinities became more evident: the Kirchners' rapprochement with Caracas, the socialist government in Chile, etc. , the changes in regional policy, the change in the international position of Colombia with the diversification and intensification of the ties of the government of President Juan Manuel Santos at regional and global levels, changes in priorities of US foreign policy, and the rise of China and other emerging powers with growing interest in the region, etc.

However, with regard to the bureaucratic elites and military leaders, the position was not the same. This is demonstrated by the primary and secondary sources accessed, and, in particular, the contents of the white papers on the defence of these nations, which, while mentioning their membership and commitments to the CDS, raised with different nuances and emphasis the need to diversify the areas and processes of the agreement and treatment of conflicts and threats regionally. Research and discussion about the role of rivalries and asymmetric perceptions in the construction of the CDS and of a regional security identity remains open.

6 The term "discursive structures" is used by (Barnes \& Duncan, 2001), and refer, according to the authors, to "the frameworks that embrace particular combinations of narratives, concepts, ideologies, and practices of meaning, each associated with a particular field of social action. 


\section{The fragmented social construction of threats in South America: diversity of myths, representations, and security discourses}

Even though South America's efforts to regionalize the visions, interpretations and spatial security practices date back many years, in general, the problems and dangers in this area are interpreted and tried to be solved at national level, as stated by Manero (2007), Nolte \& Wehner (2015), and Sánchez-Levis (2019). This is attested by the successive editions of the Defence white papers reviewed for this work. This is one of the reasons that could explain the difficulties in achieving the unification of myths posed by the neoinstitutionalist perspective as a condition for the survival and proper functioning of organizations.

On the other hand, there is diversity of discussion, management and integration models in the field of security and defence, with fora and bodies with a distinct profile in UNASUR, ALBA, and, fundamentally, the OAS. The proliferation of initiatives and regionalization and cooperation models, so diverse and with overlapping competence and functionality, is considered a "complexity" process of international defence and security institutions in South America. A process that reflects the political and ideological plurality in the region, with impacts on the organizations that act in this particular field. In their task of defining objectives and responding to common challenges, the organizations try to differentiate themselves from hemispheric and extra-regional entities and adapt to the specific needs, risks and threats, as well as the interests of the region (Bragatti, 2019: 71).

The macrosecuritization of the agenda that the United States tried to impose, based on the concept of multidimensionality of threats, generated ambiguity, disagreements and discrepancies in national approaches and lack of a hierarchical system to structure defence problems based on their zonal, neighbourhood, sub-regional and regional disaggregation (Comini, 2010). In fact, the CDS seemed to attempt an approach differentiated from that introduced in the OAS, where a Secretariat for Multidimensional Security (SMS) was created to promote and coordinate cooperation among OAS Member States, and of the latter with the Inter-American System and other entities of the International System. This aimed to evaluate, prevent, confront and respond effectively to threats to security, being the main hemispheric reference for the development of cooperation and the strengthening of the capacities of the OAS Member States, having the "Declaration on Security in the Americas" as conceptual framework (OAS, 2019). As can be seen, during the life of the CDS, conflicts did not cease to exist between strategic security representations (Padula, 2015; Sánchez-Levis, 2019).

Some countries that joined UNASUR did so with interests divergent from those of its inspiring core (Brazil and Venezuela) (Bragatti, 2019). Brazil sought a base that would reduce its vulnerabilities while boosting its global leadership project, and also contain US penetration. Venezuela promoted it as part of its counter-hegemonic and anti-imperialist platform. Colombia, after its initial reluctance to join, later modified its position by ensuring that it would have regional political support for the management of its internal conflicts, with the probable purpose of gaining some autonomy and negotiation capacity in its close, priority and asymmetric relationship with Washington. Argentina, despite its preferences for settling security issues in MERCOSUR, joined the initiative to strengthen 
its regional visibility, gain support for national causes such as the claim of the Malvinas Islands, and perhaps as part of the internal political confrontation. Chile saw it as an opportunity to avoid isolation and to deepen the diversification of the spheres in which it discusses these issues. And other smaller countries (Ecuador, Uruguay, Suriname, Guyana, etc.) took advantage of the space to strengthen their capacities to face vulnerabilities and threats.

For Comini (2010), the assignment of new functions to the Armed Forces should avoid the militarization of certain areas and the displacement of the policy-setting axis and its implementation, in a context where the asymmetric relations between the members of the CDS persist. This is in terms of regulations, organization, budgets, operational capacity, and potentiality for industrial production and research and development systems for defence - with a clear superiority of Brazil.

Ugarte (2009) insists on the need to seek coincidences and consensus in favour of a common nomenclature and that each country defines the structure that it would use in each case. He affirms that such a process was key to improve civil-military relations between member countries. He made reference to the reluctance in adopting a concept as inclusive as that adopted in the Special Conference on Security in Mexico, given that with such a concept of multidimensional security, the development agenda had been made secure in practice. He also pointed out the case of Colombia, its support of the US security agenda, unlike other Andean countries and the Southern Cone, which are more prone to building an autonomous regional agenda (11).

We agree with the views of Labadi (2018), Ugarte (2009), Sanahuja \& Francisco VerdesMontenegro (2010) in that the "Preliminary report from the CEED to the CDS on the terms of reference for the concepts of security and defence in the South American region" (CEED, 2016) was characterized by its laxity and the absence of more detailed definitions corresponding to the needs of the CDS to unify its positions and visions as to the main threats and challenges in terms of security. It should be noted, however, that the aforementioned work constitutes a reflection of a regional reality where discourses and representations compete and overlap, stemming, among other factors, from the spaces and limits imposed by the complex's own dynamics, and the length of every process of institutional construction.

\section{The limited Institutionality of the South American RSC: normative laxity and the weight of Westphalian culture}

In their approach to the RSC, Buzan \& Waever (2003) discuss the autonomous units that operate in this anarchic system. This refers to the states, whose interrelation behaviour depends on the perception of their internal vulnerabilities, the opportunities and challenges that derive from their ties with other states, and the possibilities offered by ties with extra-regional powers in managing the threats and security problems they face.

The presidential diplomacy of UNASUR - and of the foreign ministers who have acted on its behalf - played a central role in the resolution of the crises, which had direct consequences on the development of the institutional architecture of the CDS. 
In the absence of the automatic use of institutional mechanisms - of analysis, action, decisions, rewards and punishments - that could consider the intervention of technical, bureaucratic and political levels, the evidence indicates that it was the leaders of the region themselves who acted under the influence not so much or not only of the development needs and strengthening of the Council's management capacities, but of the pressures and demands of their respective internal policies. This is combined with Vargas' criterion (2018) in the sense that a formal rule can be accompanied by a strong intersubjective belief in its legitimacy (50).

This can be perfectly in tune with the statements of Powell \& Bromley (2015), in that the social construction of international organizations takes place in the external environment, from where they are provided with guidelines for their structures and formal policies. In this framework, it is the state, the area in which the bulk of the representations take place, which leads to the institution as a material network, to which it gives legitimacy and the necessary resources for its operation (Meyer \& Rowan, 1977).

As sources of the legitimacy and the resources that the CDS has had, the pressures and demands in different senses can be explained in order for it to align itself with the beliefs, myths and expectations of each of its member states, and of the groups, actors and influential sectors within them.

In the absence of defined normative and institutional frameworks, means and specific instruments for crisis management, they fell within the remit of the presidents and foreign ministers who were directly in charge of them, without standardized procedures or processes that could have acted more effectively and consistently. Despite this, the Guyana Summit, in 2010, decided to give impetus to a proposal previously made in Argentina, on the "Democratic Protocol", against "coup attempts" (Erazo, 2010), which had a greater following. Similarly, the situation of political instability in Bolivia in 2008, the coup in Honduras in 2009, the attempt in Ecuador in 2010, the creation of military bases in Colombia in 2009, the breakdown of Colombian-Venezuelan relations in 2010, and the overthrow of Paraguayan President Fernando Lugo in 2012, were among the events that received the attention and capacities of UNASUR, which remained devoid of solid institutional mechanisms to confront them. The prominence of the leaders and officials, while giving strength and impetus to the discourse in favour of the resolution of the disputes, did little favour to the maturation of the institutional architecture of the CDS.

Information on crises and negotiation processes circulated with difficulty. Sometimes three or four versions of the same issue were confronted. Very often, details and information of great relevance were known in the meetings, without there being an express mechanism to seize them, analyse them and build a solid basis for decisionmaking (Acosta, 2016).

At the same time, the CDS is part of the so-called "cooperative security schemes", defined as systems of interstate interactions that, by coordinating government policies, prevent and contain threats to national interests and prevent the perceptions the various states have from being transformed into tensions, crises or open confrontations (Comini, 2010). 
For Mijares \& Nolte (2018), UNASUR sowed, since its creation, the germ of its current crisis and self-destruction, due to its lax organizational design, the pre-eminence of national autonomies over the interests of regional integration, and the lack of a supranational institutionality that the authors call the "paradox of autonomy" (Cited in Bragatti, 2019: 70).

The countries that make up the organization maintain bilateral relations in defence matters with extra-regional countries, in areas that correspond to regional interests and in which there is still no intra-regional coordination. Topics such as the exchange of experiences in the field of humanitarian actions, the establishment of immediate response mechanisms in situations of catastrophe or natural disasters, as well as the promotion of the sovereign defence of natural resources, are some strategic aspects which, although framed in the CDS, each country continues to approach in parallel with other nations. A lack of correspondence is then evidenced between the defence systems invoked as common and the dynamics of the processes (Comini, 2010).

\section{Discussion of the results}

The use of the RSCT perspective offered us the opportunity to discuss some of its central aspects based on the empirical evidence that the research has produced. In this sense, the discussion about the definition, scope and consequences of the phenomenon of "penetration" remains open, which for Buzan \& Waever (2003) constitutes one of the most relevant conceptualization elements of a RSC. Although this work, so far, does not rethink this specific aspect of the aforementioned theory, it opens a reflection on the degree of influence that the penetration of an external power can have in the design and development of the management models of security within a Complex.

A much more heated debate arises over the question of "indifference" as a differentiating factor between the South American RSC and the one to which the United States belongs. The data collected confirm that in the calculations and representation of threats by the CDS member countries, the movements, emphasis, decisions and discursive orientations of Washington are more than relevant. This was demonstrated when the conditions for the abandonment of the Democratic Security Policy (PSD) by the Colombian government - after the election of Juan Manuel Santos - were analysed, including adjustments of the external security policy of the Colombian government to the administration of President Barack Obama, and the decision to get closer to the region through its active participation in the mechanisms and processes of multilateral and bilateral ties.

From the outset, this analysis tended to overestimate the issue of rivalries and misgivings about the rise of Brazil and its regional and global hegemonic ambitions. Later, and as the two main theoretical perspectives developed, they allowed us to distinguish two different levels of reaction and appreciation (political and bureaucratic) that placed the balance of analysis right in the middle: on the one hand, the ideological affinities acting in favour of the CDS, and, on the other, the criteria and the interpretations of the countries' military and civilian leaders, resisting the regionalization of the analyses and decisions, emphasising how the vulnerabilities and challenges increased with the integration of their respective states in the regional initiative. 
The problem of the maturation of the institutional processes of the CDS remains pending. The access limitations to oral and written primary sources made it difficult to have a finer and more complete approach to the matter. We believe that the chronological distancing of the Council's peak period could help us obtain much more information.

Even though the "futurology" exercise associated with the conflictual potential of the Amazon was risky and disruptive for the South American RSC, the truth is that the overwhelming amount of data obtained and studies conducted tend to test the theoretical claims of Buzan \& Waever (2003), who transmit, at least momentarily, the idea of permanence of the Complex, based on the hypothesis that the United States is not directly involved in a future war conflict in the region.

\section{Conclusions}

The massive penetration of the United States in the RSC, which is still very far from the "overlap" logic proposed by Buzan \& Waever (2003), considering factors such as the autonomy of its units to define security policies, friendship-enmity, and the distribution of the bulk of resources and capacities among a group of regional powers that converge and disagree. However, the US influence on the fields of management and transformation of conflicts and threats through ideas, capacities and institutions, shows an anomaly with respect to the theoretical proposal in question, and calls into question the problem of "indifference".

The Brazilian global leadership project presupposes an extraordinary accumulation of resources and capacities for its materialization. This phenomenon does not compromise "polarity" for the moment, considering the existence of other actors with enough power to gravitate towards regional politics. However, it accentuates asymmetric perceptions that tend to arouse many reservations and concerns about the future of the Complex, and indicates some "overlapping" features that would put its very existence in doubt. This could be associated with other problems such as the promotion of "penetration", adherence to other representations and material networks, and the reluctance to provide legitimacy and political support to the CDS.

Even though the efforts in South America to regionalize the visions, interpretations and spatial security practices date back many years, in general, the problems and dangers in this area are interpreted and tried to be solved nationally, resulting in fragmentation of the social construction of threats. This could be at the origin of the pitfalls that prevented the unification of the representations, interpretations and approaches within the CDS. This problem was further aggravated by the influence of the diversity of discussion, management and integration models in security and defence, with fora and bodies with a distinct profile in UNASUR, ALBA, and the OAS.

The absence of explicit norms and mechanisms for the resolution of several of the crises that broke out in the region had direct consequences on the stagnation of the development of the $\mathrm{CDS}^{\prime}$ institutional architecture. In the absence of the automatic use of institutional mechanisms that could consider the intervention of technical, bureaucratic and political levels, it was the leaders of the region themselves who acted under the influence not so much or not only of the development needs and strengthening of the 
capacities of management of the Council, but of the pressures and demands of their respective internal policies.

\section{References}

Acosta, J. (2016). Conversación sobre las capacidades del CDS-UNASUR. Quito: Author's notes.

Álvarez, G., \& Ovando, C. (2009). El Consejo de Defensa Suramericano: posibilidades de integración desde una perspectiva constructivista. Pap. Polit. Bogotá (Colombia), Vol. 2, 543-579.

Barnes, T., \& Duncan, J. (2001). Writing words.Discourse, texts and metaphor in the representation of landscape. London: Routledge.

Barrionuevo, A. (18 de mayo de 2018). Whose Rain Forest Is This, Anyway? The New York Times. Retrived from https://www.nytimes.com/2008/05/18/weekinreview/18barrionuevo.html

Battilana, J., Leca, B., \& Boxenbaum, E. (2009). How actors change institutions: towards. The Academy of Management Annals 3 (1), 65-107.

Bitar, S. E. (2016). Bases militares estadounidenses en América Latina. Revista Mexicana de Ciencias Políticas y Sociales, 625-671. Retrieved from http://www.scielo.org.mx/pdf/rmcps/v64n235/0185-1918-rmcps-64-235-625.pdf

Borda, S. (2012). Desafíos y oportunidades de la Unión de Naciones Suramericanas UNASUR. Documentos CRIES, 1-28.

Bragatti, M. C. (2019). Diez años del Consejo de Defensa Sudamericano: arquitectura de seguridad internacional regional. Geopolítica(s) Vol. 10 Núm. 1 (2019). Retrieved from https://revistas.ucm.es/index.php/GEOP/article/view/59777

Buzan, B., \& Waever, O. (2003). Regions and Powers The Structure of International Security. London: Cambridge University Press.

Buzan, B., Waever, O., \& Wilde, J. d. (1998). Security A New Framawork for Analysis . Colorado: Lynne Rienner Publishers.

Capote, R. (9 de agosto de 2018). Bases militares de EE.UU. en América Latina y el Caribe. El Plan Suramérica. Granma. Retrieved from http://www.granma.cu/mundo/2018-08-09/bases-militares-de-eeuu-en-americalatina-y-el-caribe-el-plan-suramerica-09-08-2018-17-08-04

Cardoza, J. A. (2010). El liderazgo sudamericano de Brasil: los difíciles caminos del consenso y la hegemonía. Agenda Internacional Año XVII, No. 28, 237-248. Retrieved from https://dialnet.unirioja.es/descarga/articulo/6302485.pdf

Cassese, A. (1986 ). Le droit international dans un monde divisé. Paris .

CEED. (2016). Informe preliminar del CEED al CDS acerca de los términos de referencia para los conceptos de seguridad y defensa en la región suramericana. Caracas: Secretaria UNASUR. 
Chávez, H. (26 November 2010). Declaraciones del Comandante Presidente Hugo Chávez a la salida de la IV Cumbre Extraordinaria de Jefes de Estado y de Gobierno de la Unasur. Retrieved from Todo Chávez: http://www.todochavezenlaweb.gob.ve/todochavez/715declaraciones-del-comandante-presidente-hugo-chavez-a-la-salida-de-la-iv-cumbreextraordinaria-de-jefes-de-estado-y-de-gobierno-de-la-unasur

Comini, N. (2010). El rol del Consejo de Defensa de la Unasur en los últimos conflictos regionales. Nueva Sociedad Noviembre-Diciembre 2010. Retrieved from https://nuso.org/articulo/el-rol-del-consejo-de-defensa-de-la-unasur-en-los-ultimosconflictos-regionales/

Congreso de la Nación, S. (1998). Ley 24.948. Buenos Aires: Congreso de la Nación de la República Argentina.

Cox, R. (1981). Social Forces, States and World Orders: Beyond International Relations Theory. Millennium - Journal of International Studies 1981, Vol. 10, No.2, 126-155.

Diez de Velazco, M. (1997). Las organizaciones internacionales. Madrid: Tecnos .

DiMaggio, P. (1988). Interest and agency in institutional theory. In L. Z. (Ed.), Institutional Patterns and Organizations: Culture and Environment (pp. 3-22). Cambridge, MA: Ballinger Publishing Company.

Eisenstadt, S. (1980). Cultural orientations, institutional entrepreneurs, and social: comparative analysis of traditional civilizations. American Journal of Sociology 85 (4), 840-869.

Elias, N. (2003). Ensayo acerca de las relaciones entre los establecidos y los forasteros. Reis, 219-251.

Erazo, P. M. (27 November 2010). Cumbre de Unasur acuerda un protocolo contra golpes de Estado. Retrieved from https://www.bbc.com/mundo/noticias/2010/11/101126_colombia_ecuador_relaciones_ restablecimiento_unasur_jg

Fernández, S. (2012). 1Una nueva visión de la seguridad hemisférica en América Latina. El caso deBrasil frente a la visión hegemónica deEstados Unidos. Buenos Aires: Universidad Colegio Mayor de Nuestra Señora del Rosario.

Flemes, D., Nolte, D., \& Wehner, L. (2011). Una comunidad de seguridad regional en formación: la Unasur y su Consejo de Defensa. Estudios Internacionales 170, 105-127.

Freeman, G. C. (2005). El Nuevo Concepto de Seguridad Hemisférica de la OEA: Una Amenaza en Potencia. Washington: WOLA.

Gandásegui, M., Martins, C., \& Vommaro, P. (2015). Soberanía, hegemonía e integración de las democracias en revolución en América Latina. Quito: IAEN.

García, C. A. (2010). La inserción internacional de Sudamérica: la apuesta por la Unasur. Íconos Num. 38, Quito, 29-40.

Gobierno-Argentina. (1998). Libro Blanco de la República Argentina. Buenos Aires: Ministerio de Defensa.

Gobierno-Argentina. (2010). Libro Blanco. Buenos Aires: Ministerio de la Defensa . 
Gobierno-Argentina. (2015). Libro Blanco de la Defensa 2015. Buenos Aires: Ministerio de la Defensa. Retrieved from http://ceed.unasursg.org/Espanol/09-Downloads/InfoPais/Arg/LB/Libro_blanco_2015.pdf

Gobierno-Brasil. (2007). Estrategia Nacional de Defensa. Brasilia: Ministerio de Defensa de Brasil. Retrieved from https://www2.gwu.edu/ clai/recent_events/2010/Brazil_Defense/Estrategia_Nacional_ de_Defensa.pdf

Gobierno-Brasil. (2012). Libro Blanco de la Defensa de Brasil. Brasilia : Ministerio de Defensa.

Gobierno-Chile. (2017). Libro de la Defensa Nacional de Chile. Santiago de Chile: Ministerio de Defensa. Retrieved from https://www.defensa.cl/media/LibroDefensa.pdf

Griffiths, J. E. (2007). Seguridad Hemisférica en. GCC, 88-104. Retrieved from https://gcg.universia.net/article/download/312/438

Grupo de Trabajo del CDS, C. d. (2009). El Consejo de Defensa Sudamericano. Crónica de su gestación. Santiago de Chile: Alerce.

Gudynas, E. (2006). Las cumbres sudamericanas y la búsqueda de un nuevo marco de integración regional. La r@/. Retrieved from http://www6.rel-uita.org/index.html

Guevara, G. D. (2017). Intervencionismo y medio ambiente: el caso de la Amazonía Brasileña. rev.relac.int.estrateg.segur. vol.12 no.1 Jan./June 2017. doi:http://dx.doi.org/10.18359/ries.2470

Joint-Chiefs-of-Staff. (2018). Joint Vision 2020. Washington: Joint Chiefs of Staff. Retrieved from http://pentagonus.ru/doc/JV2020.pdf

Kersffeld, D. (2010). Una nueva agenda para Sudamérica: la UNASUR y la resolución de conflictos internacionales. Línea Sur, 71-86.

Labadi, M. (2018). Entrevista sobre el CEED y la coyuntura del CDS. Quito: Author's notes.

Lissardy, G. (8 November 2011). Los temores ante Brasil, el nuevo imperio americano. BBC News Mundo. Retrieved from https://www.bbc.com/mundo/noticias/2011/11/111108_america_latina_brasil_imperial -aa

Livoti, E. (2019). Conversación sobre la posición argentina ante el CDS. Quito: Author's notes.

Luongo, M. (2018). Conversación sobre la posición argentina ante el CDS. Buenos Aires: Author's notes.

Mackinder, H. (1904). The Geographical Pivot of History. Geographical Journal, Royal Society of London, 436.

Mahan, A. (1912). The place of force in international relations. New York: Harper and Brothers Publishers.

Manero, E. (2007). Strategic Representation and Borderareas: Latin America and Global Disorder. Taylor \& Francis (Routledge), 2007, Vol 12 (1 January-March), pp. 19-56. 
Martínez, Á. (2016). "Seguridad Hemisférica: ¿respecto a qué?, ¿por quién? Un paso adelante en la búsqueda del modelo. HSDL, 131-163.

Martínez, F. (15 September 2015). No habría cumbre de presidentes de Unasur para tratar crisis colombo venezolana. Radio Nacional de Colombia. Retrieved from https://www.radionacional.co/noticia/presidentes-de-unasur-convocados-el-proximolunes-21-de-septiembre

Mena, P. (30 July 2010). Unasur no logra consenso entre Venezuela y Colombia. BBC. Retrieved from https://www.bbc.com/mundo/america_latina/2010/07/100730_unasur_no_consenso_c olombia_venezuela_lh

Meyer, J. W., \& Rowan, B. (1977). Institutionalized Organizations: Formal Structure as Myth and Ceremony. The American Journal of Sociology, Vol. 83, No. 2. (Sep., 1977), 340-363.

Montenegro, J. L. (2011). La geopolítica en Sudamérica: conflictos potenciales y efectos globales. Investigaciones Geográficas, no. 55, 113-133.

NATO. (6 December 2018). Relations with Colombia. Retrieved from https://www.nato.int/cps/en/natohq/topics_143936.htm

Navarro, S., \& Bessi, R. (2017). Ocupación silenciosa del Comando Sur de EEUU en la Amazonía. Avispa Midi. Retrieved from https://avispa.org/ocupacion-silenciosa-delcomando-sur-de-los-ee-uu-en-la-amazonia/

Nolte, D., \& Wehner, L. (2015). Geopolitics in Latin America, Old and New. Routledge Handbook of Latin American Security Routledge.

OEA. (2019). Sscretaría de Seguridad Multidimensional. Retrieved from OEA: http://www.oas.org/es/ssm/template.asp?File=/es/ssm/default.asp

Padula, R. (2013). A Geopolítica da Bacia do Pacífico e a integração regional na América. RevIU, 30-47.

Padula, R. (2015). A disputa pela agenda de seguranca regional e o conselho de defesa sul-americano. R. Esc Guerra Naval, Rio de Janeiro, v. 21, n. 2, , 221-262.

Paladines, S. L. (2017). Ecuador y el Consejo de Defensa Sudamericano: un análisis de los criterios de seguridad nacional para la concertación de una Política de Defensa Común en la región. Quito: PUCE. Retrieved from http://repositorio.puce.edu.ec/bitstream/handle/22000/13365/ECUADOR\%20Y\%20EL \%20CONSEJO\%20DE\%20DEFENSA\%20SUDAMERICANO\%20UN\%20ANÁLISIS\%20DE $\% 20 L O S \% 20$ CRITERIOS $\% 20$ DE $\% 20$ SEGURIDAD $\% 20$ NACIONAL\%20P.pdf?sequence $=1$ \&isAllowed $=y$

Pastor, M. (2017). Más tropas de EEUU en América Latina: señales de una invasión. HispanTV. Retrieved from https://www.hispantv.com/noticias/opinion/357196/americalatina-base-militar-invasion-amazonia

Pastrana, E. (2011). Evolución y perspecivas de las relaciones entre Colombia y Brasil . In B. Sorji, \& S. Fausto, Brasil y América del Sur: Miradas cruzadas (pp. 75-116). Buenos Aires: Catálogos S.R.L. 
Pierson, P., \& Skocpol, T. (s-f). Historical Institutionalism in contemporary political science.

Powell, W., \& Bromley, P. (2015). New Institutionalism in the Analysis of Complex. In J. D. Wright, International Encyclopedia of the Social \& Behavioral Sciences, 2nd edition, Vol. 16 (pp. 764-769). Oxford: Elsevier. Retrieved from https://www.researchgate.net/publication/304191140_New_Institutionalism_in_the_An alysis_of_Complex_Organizations

Presidencia-Brasil, S. (2004). Projeto Brasil 3 Tempos: 2007, 2015 e 2022. Brasilia. Retrieved from www.biblioteca.presidencia.gov.br/...brasil-3-tempos.../01brasil3t....

Rebollar, V. (2010). Discurso geopolítico brasileño en el marco de la creación de la Uniónde Naciones Suramericanas(UNASUR). México DF: FLACSO Mexico.

Rivas, P. (2019). Entrevista sobre la percepción en Chile del ascenso brasileño. Quito: Author's notes.

Rodríguez, L. V., \& Plazas, L. G. (2012). Amazonía: la disputa entre los espacios ancestrales y los intereses imperialistas. Memoriadel XViii Forode estudiantes latinoaMericanosde antropología y arqueología, 448-471.

Sanahuja, J. A., \& Francisco Verdes-Montenegro. (2010). Seguridad y defensa en Suramérica: regionalismo, cooperación y autonomía en el marco de UNASUR. Anuario de Integración 10, 487-529.

Sánchez-Levis, R. P. (2019). Pugna entre modelos de representación estratégica de seguridadde la pos Guerra Fría y el papel de las "nuevas viejas amenazas": el caso de la Unión de Naciones Suramericanas. Estado \& Comunes, 155-183.

Schenoni, L. (2014). Brasil en América del Sur. La lógica de la unipolaridad regional . Nueva Sociedad No 250, 138-149.

Serrano, L. O. (2017). Chile en la UNASUR: percepciones de actores clave sobre la organización. Estudios internacionales (Santiago). Retrieved from https://scielo.conicyt.cl/scielo.php?script=sci_arttext\&pid=S0719-37692017000400009

Teixeira, A. M. (2010). Regionalismo y seguridad sudamericana: ¿son relevantes el Mercosur y la Unasur? Íconos. Revista de Ciencias Sociales. No. 38, Quito, September 2010, 41-53.

Thornton, P. H., \& Ocasio, W. (2008). Institutional Logics. In The SAGE Handbook of Organizational Institutionalism (págs. 100-129). Publisher: Sage Publications Ltd.

Tidd, K. (2018). Posture Statement. Washington: United States Southern Command.

Toledo, L. C. (2017). Geopolítica en América del Sur: Desde la militarización de la disciplina a la necesidad del debate académico. Revista Chilena de Derecho y Ciencia Política, 165-184.

Tuathail, G. (2005). Critical Geopolitics. London: Taylor \& Francis e-Library.

Ugarte, J. M. (2009). El Consejo de Defensa Suramericano: Balance y perspectivas. Buenos Aires: Ministerio d e Defensa República Argentina. Retrieved from http://www.fes.org.ar/Publicaciones/2010/PAPER_Ugarte_Mayo_2010.pdf 
UNODC. (2018). Informe Mundial sobre las Drogas. Vienna: UNODC.

Vargas, J. (2008). Perspectivas del Institucionalismo y Neoinstitucionalismo. Universidad Veracruzana. Retrieved from https://www.uv.mx/iiesca/files/2012/12/perspectivas2008-1.pdf

Vasconcelos, J. (. (1937). Hispanoamericanismo y panamericanismo. Temas Iberoamericanos, 3rd ed., 9-21.

Visca, P. (2008). Cumbre Brasilia 2008: El lanzamiento de UNASUR en el tablero del poder. Integración Sur. Retrieved from http://integracionsur.com/cumbre-brasilia-2008el-lanzamiento-de-unasur-en-el-tablero-del-poder/

Zamora, P. (13 September 2015). El encuentro entre Santos y Maduro no cuajó en Quito. El Comercio. Retrieved from https://www.elcomercio.com/actualidad/unasur-celaccrisis-colombia-venezuela.html 